\title{
"Problems experienced by secondary school deputy principals in diverse contexts: a South African study"
}

\begin{tabular}{|c|c|}
\hline \multirow{2}{*}{ AUTHORS } & $\begin{array}{l}\text { Jan B Khumalo } \\
\text { Herman J van Vuuren (D https://orcid.org/0000-0002-5217-9888 }\end{array}$ \\
\hline & $\begin{array}{l}\text { Philip C van der Westhuizen } \\
\text { C.P. Van der Vyver (D) https://orcid.org/0000-0003-0424-5593 }\end{array}$ \\
\hline ARTICLE INFO & $\begin{array}{l}\text { Jan B Khumalo, Herman J van Vuuren, Philip C van der Westhuizen and C.P. } \\
\text { Van der Vyver (2018). Problems experienced by secondary school deputy } \\
\text { principals in diverse contexts: a South African study. Problems and Perspectives } \\
\text { in Management, 16(2), 190-199. doi:10.21511/ppm.16(2).2018.17 }\end{array}$ \\
\hline DOI & http://dx.doi.org/10.21511/ppm.16(2).2018.17 \\
\hline RELEASED ON & Monday, 21 May 2018 \\
\hline RECEIVED ON & Monday, 13 November 2017 \\
\hline ACCEPTED ON & Friday, 30 March 2018 \\
\hline LICENSE & $\begin{array}{l}(c) \text { EY } \\
\text { This work is licensed under a Creative Commons Attribution } 4.0 \text { International } \\
\text { License }\end{array}$ \\
\hline JOURNAL & "Problems and Perspectives in Management" \\
\hline ISSN PRINT & $1727-7051$ \\
\hline ISSN ONLINE & $1810-5467$ \\
\hline PUBLISHER & LLC "Consulting Publishing Company "Business Perspectives" \\
\hline FOUNDER & LLC "Consulting Publishing Company "Business Perspectives" \\
\hline
\end{tabular}

NUMBER OF REFERENCES

33

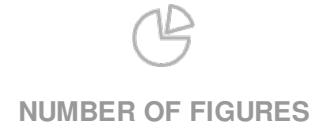

0
NUMBER OF TABLES

3

(C) The author(s) 2022. This publication is an open access article. 


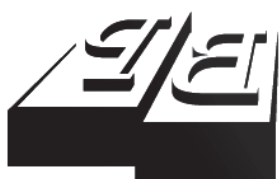

BUSINESS PERSPECTIVES

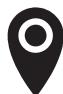

LLC "CPC "Business Perspectives" Hryhorii Skovoroda lane, 10, Sumy, 40022, Ukraine

www.businessperspectives.org

Received on: $13^{\text {th }}$ of November, 2017 Accepted on: $30^{\text {th }}$ of March, 2018

(C) Jan B Khumalo, Herman J Van Vuuren, Philip C Van de Westhuizen, C.P. Van der Vyver, 2018

Jan B Khumalo, Ph.D., Member of EDULEAD Research Niche, Faculty of Education Sciences, North West University Potchefstroom Campus, South Africa.

Herman J Van Vuuren, Ph.D. Associate Professor, Director of the School of Language Education, North West University Potchefstroom Campus, South Africa.

Philip C Van der Westhuizen, Ph.D.,Extra-ordinary Professor, Faculty of Education, North-West University, South Africa.

C.P. Van der Vyver, Ph.D., Senior lecturer, School of Professional Studies in Education, Faculty of Education, North-West University, South Africa.

\section{(ㄷ)(i)}

This is an Open Access article, distributed under the terms of the Creative Commons Attribution 4.0 International license, which permits unrestricted re-use, distribution, and reproduction in any medium provided the original work is properly cited.
Jan B Khumalo (South Africa), Herman J Van Vuuren (South Africa), Philip C Van der Westhuizen (South Africa), C.P. Van der Vyver (South Africa)

\section{PROBLEMS EXPERIENCED}

BY SECONDARY SCHOOL DEPUTY PRINCIPALS IN DIVERSE CONTEXTS: A SOUTH AFRICAN STUDY

\begin{abstract}
This paper reports on research that was undertaken to determine the problems experienced by deputy principals in secondary schools, and the extent to which these problems were experienced. Although some research was conducted on the deputy principalship, no research treats the problems that deputy principals experience upon appointment comprehensively. An understanding of the problems experienced by secondary school deputy principals is a necessary precursor of an induction program to address the problems. A quantitative approach which was underpinned by the post-positivist paradigm was adopted. In order to determine the extent to which the problems were experienced, a survey was conducted among one hundred and fifty seven secondary school deputy principals in the North West Province. The participants came from a diverse context of rural, township and urban schools. The deputy principals who participated in the study included those who were newly appointed (one to three years of service) and those who were experienced (more than three years of service). Data were analyzed by means of descriptive statistics such as frequencies, means and percentages. There were no significant differences in the responses of both newly-appointed and experienced deputy principals. The results revealed that deputy principals experienced administrative, financial management, work pressure, personal and physical resources problems. In an attempt to address the problems identified, a context-specific induction program is recommended. The induction program should be an on-going program of professional development and should preferably include specific aims, action steps to be taken to achieve the aims that are set and measures to evaluate progress.
\end{abstract}

\section{Keywords}

problems, deputy principals, induction, induction programme, professional development, leadership, management

\section{JEL Classification I24, I21}

\section{INTRODUCTION}

The professional development of deputy principals is an area that has been neglected in the studies on school leadership development and this seems to be a global problem. Although some research has been conducted on the deputy principalship (Barnett, Shoho, \& Oleszewski, 2012; Harris, Muijs, \& Crawford, 2003; Potgieter, 1990), no study focuses specifically on the problems that deputy principals experience upon appointment. These problems affect the adaptation of deputy principals to their new role and consequently impact their induction and on-going professional development.

The lack of literature on the deputy principalship is problematic given the fact that many deputy principals aspire to principalship and therefore need to be prepared for this future role. Harris et al. (2003) concur that deputy principals often receive inadequate professional support in their position and role. Moreover, professional development of 
school leaders is a crucial need in all schools, yet it seems to be neglected (Boyle, Lamprianou, \& Boyle, 2005; Msila \& Mtshali, 2011; Steyn, 2011), particularly for deputy principals.

It is therefore crucial to understand the dynamics of the deputy principalship, especially problems experienced by deputy principals. Since the position of deputy principal may be considered as an assessment position for promotion to the principalship, on-the-job training is as important as off-the-job development program in nurturing future school leaders (Greenfield, 1985; Kwan, 2009; Marshall, 1992).

Accordingly, the purpose of the research was to identify the problems experienced by deputy principals and the extent to which these problems were experienced. The problems were identified from the literature on the deputy principalship, including relevant government policies on the duties and responsibilities of deputy principals. Thereafter, the extent to which the identified problems were experienced was determined empirically using a standardized questionnaire and different statistical techniques.

\section{LITERATURE REVIEW}

In this section, the theoretical and conceptual frameworks upon which this study was based are presented. Firstly, the theoretical framework which rests upon the model that underpins the tasks and areas of education management is described and, secondly, a conceptual framework which is used to provide the context for problems that are experienced by educators across the different post levels in the South African education system, including deputy principals, is presented.

The model which provides an understanding of the duties and potential problem areas of the deputy principal is the management task-area model, which explains the different areas of school management within which the deputy principal is expected to perform management work. This model was used by Van der Westhuizen (1991) in his pioneering work on educational management in South Africa. More recent work draws from this model and illustrates the management tasks and areas of education managers such as deputy principals (Heystek, 2012; South Africa, 1999; Van Deventer, 2016). The management task-area model identifies four main management tasks, which are performed by education managers, namely, planning, organizing, leading and controlling (Van Deventer, 2016). The management areas of the deputy principal are performed within these management tasks. The management areas of the deputy principal include the management of personnel, learners, the curriculum, physical and financial resources and relationships with the school community. Van Deventer (2016) elaborates fur- ther that the areas in education management are learner affairs, staff affairs, administrative affairs, financial affairs, physical facilities and school community relations. The management areas revealed here are not exhaustive, because in some education systems, deputy principals perform duties that are delegated by the principal, and the principal decides which duties to delegate. The consensus by scholars on the management areas of educational managers reinforces the view about the duties and responsibilities of deputy principals in South African schools. Based on the evidence in the literature and the results of the study which are reported later on, it is assumed that deputy principals may experience problems in their management work if they have not been provided with professional development.

The problems experienced by deputy principals constitute a typology which is generic and which represents clusters of problems which are experienced by educators subsequent to appointment in a new post. Although the problems are relevant to the local context, scholars who focus on the deputy principalship globally may relate them to their contexts.

There are similarities among clusters of problems identified by several authors whose work was consulted for this study. For instance, the problems for new principals identified by Legotlo (1994) and Kitavi (1995) were similar to those experienced by deputy principals (Potgieter, 1990; Barnett et al., 2012), circuit managers (Smit, 2002), school managers (Seipobi, 2012) and newly appointed teachers (Grayson \& Alvarez, 2008). Other authors whose 
work was consulted also corroborate the similarity amongst problems experienced by newly appointed educators (Maake, 2013; Le Maistre \& Pare, 2010; Somo, 2007) and lend support to the argument made for problems experienced by deputy principals. Moreover, "the challenges of assistant principals (deputy principals) are similar to what beginning principals have reported" (Barnett et al., 2012, p. 96).

In the South African context, one of the most useful policy guidelines which highlights the duties and responsibilities of the deputy principal and which contextualizes the problems experienced by deputy principals is the Personnel Administrative Measures (PAM) (South Africa, 1999). The PAM document reveals management performance areas for deputy principals in the following manner: general or administrative duties, teaching, extra and co-curricular duties, personnel management, interaction with stakeholders and communication (South Africa, 1999). It is necessary to elaborate on each of these clusters of management areas in order to highlight potential problem areas for deputy principals.

\subsection{General or administrative duties}

In the management task-area model one of the management areas is indicated as administrative affairs (Van Deventer, 2016). Although the PAM document groups/clusters/aggregates general and administrative duties together, this paragraph focuses only on administrative duties which deputy principals are required to perform in the daily operations of their schools. The foremost duty of the deputy principal is to assist the principal and to deputize for them during their absence from school. This is quite an important duty given that school contexts differ and the deputy principal may need more time to perform this duty depending on the size of the school and their allocated subjects to teach. Actually, the deputy principal may be instructed to be responsible for school administration, which entails, among others, duty roster, arrangements to cover for absent staff, internal and external evaluation and assessment, school calendar, admission of new learners, class streaming and school functions (South Africa, 1999). Therefore, the number of deputy principals in a school has implications for the workload to be shared and time management and may create administrative problems, which deputy principals have to contend with.

Other administrative duties entail the management of financial and physical resources. The deputy principal is required to assist the principal with school finance and maintenance of services and buildings, such as planning and control of expenditure and allocation of funds/resources. Financial monitoring and control requires that whoever is delegated financial management duties, in this case the deputy principal, should ensure that checks are in place to ensure that goals are achieved, sound accounting practices are implemented and information is shared (Mestry \& Bisschoff, 2009). Notwithstanding this, school managers or deputy principals, if delegated financial management duties, need to receive guidance with budgeting and financial management as the areas where they have the greatest development needs (Cranston, Tromans, \& Reugebrink, 2004; Mestry \& Bisschoff, 2009).

Problems experienced with the management of physical resources include supervising annual stock-taking and allocation of resources. The school's physical resources are its tangible assets such as buildings, equipment, furniture, machinery, and teaching and learning materials (Mentz, Challens, \& Kruger, 2016). The deputy principal is required to assist the principal with, among others, the allocation of resources and supervising annual stock-taking (South Africa, 1999). In order to manage the school's physical resources effectively, tasks such as planning for the use of resources, obtaining the resources, ensuring the availability of suitable supplies, monitoring the use of resources and exercising proper control should be performed. In order to be able to manage the resources effectively, the deputy principal is expected to plan thoroughly as indicated in the management task-area model.

\subsection{Teaching}

The management task-area model identifies curricular affairs or teaching as one of the management areas of deputy principals (Van Deventer, 2016). Accordingly, deputy principals are ex- 
pected to spend $60 \%$ of their time at school on teaching, but this may vary depending on the size of the school. The same applies for both primary and secondary school deputy principals. Consequently, deputy principals may be required to do more in smaller schools than they would in relatively bigger schools. Therefore, the actual teaching hours must be established in relation to the curriculum needs of the school, the timetable and the staff establishment (South Africa, 1999). In addition to classroom teaching, the deputy principal is expected to assess learners according to the requirements of assessment policies and to record their attainment. An exploration of the role of deputy principals should therefore be cognizant of the teaching problems that deputy principals may experience apart from their administrative duties.

\subsection{Extra and co-curricular duties}

Extra and co-curricular affairs are part of the deputy principal's management areas as highlighted in the management task-area model (Van Deventer, 2016). One of the management duties of the deputy principal is to serve in various committees in the school. This role entails serving in such committees as recruitment, promotion, advisory and other relevant committees, which may be established in the school (South Africa, 1999). In this vein, the deputy principal is expected to provide leadership and to establish sound relations with colleagues who serve in those committees. Serving in such committees may also require the deputy principal to demonstrate awareness of how to use their power or authority to get things done.

\subsection{Personnel management}

Personnel management or staff affairs are a crucial management area for deputy principals in the light of the management task-area model (Van Deventer, 2016). The current practice regarding the personnel management duties of deputy principals is to manage staff such as departmental heads. The deputy principal is expected to guide and supervise the work and performance of staff and to discuss and write or countersign reports (South Africa, 1999). In terms of the Integrated Quality Management System (IQMS), the deputy principal is required to serve in appraisal committees of staff as one of their crucial personnel management duties. Participation in appraisal processes enables the deputy principal to regularly review the professional practice of staff in order to improve teaching, learning and management. Problems are likely to be experienced if there is no cooperation between the deputy principal and educators whose appraisal panel they serve in.

It is therefore crucial that the deputy principal should build relationships with the different role-players who are involved in the appraisal process. The building of relationships determines the contentment and work satisfaction of the various people at work. Establishing relationships is important at schools, because only people are capable of achieving educational objectives, establishing good relationships, facilitating healthier interpersonal relationships, and people are dependent on one another for their continued existence (Van der Westhuizen, 1991).

Personnel management for the deputy principal may also cause personal and work pressure problems, which will require professional intervention in their work life. Stress is identified as one of the work pressure problems that deputy principals experience in the education system (Peloyahae, 2005). There is evidence in the literature to suggest that new school leaders experience tension, particularly when they have to apply their textbook understanding of school leadership to the practical school situation (Legotlo, 1994; Lashway, 2003). The role of the deputy principal has been found to be stressful, formal and administrative-oriented (Oplatka \& Tamir, 2009). Moreover, deputy principals experience resistance and tension when working with teachers who are weak, have low morale or are not child-centered (Barnett et al., 2012).

\subsection{Interaction with stakeholders}

The management task-area model postulates that the area of school community affairs and governance is performed under the leadership, direction and guidance of the school manager (Van Deventer, 2016). In practice, this management area is often delegated to the deputy principal. 
Although the deputy principal may be delegated duties to interact with different stakeholders such as the community, departmental officials, educators and SMTs of neighboring schools and subject advisors, the deputy principal's duties and responsibilities require them to work with the Representative Council of Learners (RCL). The RCL comprises learners from each class in a secondary school ranging from Grade 8 up to Grade 12. The deputy principal is expected to supervise/advise the RCL (South Africa, 1999), so that they can play their role in a school constructively. Owing to the fact that learners who serve in the RCL have no formal leadership training, they need a professional educator to show them the ropes. Moreover, RCL learners are perceived to be too inexperienced to deal with matters affecting the school (Mncube, 2008), that is why they need to be supported in this role. Research conducted on RCLs in South African schools covers several areas of their functioning (Mathebula, 2005; Mncube, 2008) and necessitates a claim in this paper that problems may be experienced with the functioning of the RCL if they are not provided with enough development opportunities, which are known as "capacity building workshops" in the South African context.

\subsection{Communication}

Communication is a sub-task of leading or directing which is one of the main tasks of the management task-area model (Van Deventer, 2016). The deputy principal is expected to communicate and to liaise with different role-players on behalf of the principal. The communication may take the form of meeting with parents, government departments, sporting, social, cultural and community organizations (South Africa, 1999). When the deputy principal meets with parents of learners enrolled in a school, the purpose of such meetings is normally to discuss learners' progress and behavior. Other bodies with an interest in the school also interact with the deputy principal when this duty is delegated and because the principal may not have enough time to meet with all the role-players. Accordingly, the deputy principal may be expected to make time for this role, which may consequently result in a lack of sufficient time and competing priorities for the deputy principal.

\section{AIMS}

The aim of the research was to determine the problems experienced by deputy principals and the extent to which these problems were experienced. Consequently, the study sought to recommend measures to address these problems.

\section{METHODS}

The study adopted a quantitative approach, underpinned by the post-positivist paradigm (Cohen, Manion, \& Morrison, 2011; Creswell, 2014). The adoption of the post-positivist stance was occasioned by the authors' assumption that there is no neutral truth and that the participants should be allowed to provide narrative responses about the problems experienced by deputy principals. In order to achieve the research aim as stated above, a survey was conducted. This was achieved by measuring the extent to which deputy principals experienced the problems that were identified. Surveys gather data at a particular point in time with the intention to describe the nature of existing conditions (Cohen et al., 2011).

\subsection{Population and sampling}

The population comprised all secondary school deputy principals in the North West Province. Initially, a census sample was used to select the respondents, but when the return rate became poor, a convenient sample of deputy principals attending a conference organized by their teacher union was utilized. A convenient sample is used when the researcher simply chooses the sample from those to whom he has easy access (Cohen et al., 2011; Maree \& Pietersen, 2016). The participants came from a diverse context of rural, township and urban schools. The deputy principals who participated in the study included those who were newly appointed (one to three years of service) and those who were experienced (more than three years of service). A total of 200 questionnaires were distributed and 157 (78.5\%) usable questionnaires were received back. This number, 157 out of 200 questionnaires, constitutes $42 \%$ of the population of secondary school deputy principals in the North West Province. Accordingly, the results of the study cannot be generalized to the wider population of deputy principals in the North West Province. 


\subsection{Data collection}

A questionnaire with 85 items was developed and administered to the respondents to obtain their views on problems experienced by deputy principals (Khumalo, Van Vuuren, Van der Westhuizen, \& Van der Vyver, 2017). It was developed from the theoretical constructs of problems experienced by deputy principals, which were identified from the literature. The questionnaire was designed in a similar way to the one developed by Legotlo (1994) for newly appointed principals in the North West Province of South Africa. However, most of the items in Legotlo's (1994) questionnaire were revised and aligned with the PAM document, which highlights the duties and responsibilities of deputy principals in South African schools. The response options in the questionnaire which the respondents were required to consider included: $1=$ to almost no extent; 2 = to a small extent; $3=$ to some extent; 4 = to a large extent.

Before the questionnaire was administered to deputy principals, an exploratory study was conducted with five deputy principals who were not part of the study population. The respondents commented on the design of the questionnaire, which included aspects such as clarity of items and the time it took to complete the questionnaire. The comments of the respondents during the exploratory study were taken into account during the finalization of the questionnaire.

\subsection{Validity and reliability of the questionnaire}

To ensure the content validity of the questionnaire, the items in the questionnaire were constructed to address the problems experienced by deputy principals, which had been identified from the literature. The questionnaire was also given to specialists in the field of educational management who were asked to provide critical comments about its contents. The construct validity of the questionnaire was ensured by exploratory and confirmatory factor analyses. To determine the internal consistency of the items in the questionnaire, Cronbach's alpha coefficients were calculated. Cronbach's alpha values higher than 0.60 were reported. These values indicate an acceptable degree of reliability for the questionnaire. The Cronbach's alpha values of serious problems for deputy principals are reported in Table 1.

Table 1. Cronbach's alpha values of serious problems for deputy principals

\begin{tabular}{l|c}
\hline \multicolumn{1}{c|}{ Problems } & Values \\
\hline Administrative & 0.67 \\
\hline Financial management & 0.78 \\
\hline Work pressure & 0.80 \\
\hline Personal & 0.66 \\
\hline Physical resources & 0.74 \\
\hline Staff & 0.85 \\
\hline
\end{tabular}

\subsection{Ethical aspects}

The authors obtained permission from the Department of Basic Education in the North West Province. Permission was also obtained from a teacher union to administer questionnaires to secondary school deputy principals who were attending their conferences. The Ethics Committee of the university also granted permission to conduct the research. The cover letter on the face of the questionnaire addressed ethical aspects such as voluntary participation, anonymity and the right to withdraw from the study if the participants chose to do so.

\subsection{Data analysis}

Data were analyzed by means of descriptive statistics such as frequencies, means and percentages. Descriptive statistics were used to determine the extent of problems newly appointed deputy principals experience. The problems were ranked from those that are experienced to a small extent up to those that are experienced to a large extent. The constructs and items with a mean score of 2.5 and above were regarded as those that were experienced to a large extent by deputy principals and these were the only problems that are reported in this article. There were no differences in the responses of newly appointed and experienced deputy principals.

\section{RESULTS}

The problems experienced by deputy principals were ranked from those that are experienced to almost no extent to those that are experienced to a large extent. The ranking was done by means of 
mean scores for each problem, as well as for each individual item comprising the problem. In this article, problems and items with mean scores higher than 2.5 are regarded as those experienced to some extent up to a large extent and therefore regarded as serious problems experienced by deputy principals. The study revealed that the problems that were experienced to a large extent by deputy principals included problems such as administrative, financial management, work pressure, personal, physical resources, and staff problems. The mean scores of problems experienced by deputy principals in rank order are presented in Table 2.

Table 2. Mean scores of problems experienced by deputy principals in rank order

\begin{tabular}{c:c|c}
\hline Ranking & Problems & Mean scores \\
\hline 1 & Administrative & 2.64 \\
\hdashline 2 & Financial management & 2.58 \\
3 & Work pressure & 2.57 \\
\hdashline 4 & Personal & 2.55 \\
\hdashline 5 & Physical resources & 2.54 \\
\hdashline 6 & Staff & 2.53 \\
\hline
\end{tabular}

Similarly, the mean scores of the individual items for each cluster of problems are presented in Table 3. The discussion in the next section of this article includes both the problems and the individual items of problems experienced by deputy principals.

\section{DISCUSSION}

\subsection{Administrative problems}

Deputy principals reported that they experienced problems such as too much administrative work (mean 2.88), lack of sufficient time for administrative work (mean 2.57), evaluating staff effectively (mean 2.55) and conducting effective classroom visits (mean 2.52). Deputy principals need enough time to do non-teaching work and therefore need more time for administrative work. The fact that the deputy principal's work is demanding implies that there will be competing priorities for the deputy principal, which has implications for time management. Staff evaluation and conducting classroom visits are also problematic areas for deputy principals in view of the different viewpoints of unions regarding the objectivity of unannounced classroom visits. Moreover, secondary school deputy principals spend $60 \%$ of their time teaching and only $40 \%$ on administration (South Africa, 1999), but they need more time for administrative work.

\subsection{Financial management problems}

The financial management problems that were experienced included planning (mean 2.65) and controlling (mean 2.54) school finance. School finan-

Table 3. Descriptive statistics of problems experienced by deputy principals

\begin{tabular}{|c|c|c|c|c|c|c|c|c|c|c|c|c|}
\hline \multirow{3}{*}{ Rank } & \multirow{3}{*}{ Problems } & \multirow{3}{*}{ Description } & \multirow{3}{*}{ Mean } & \multirow{3}{*}{ SD } & \multicolumn{8}{|c|}{ Responses } \\
\hline & & & & & \multicolumn{2}{|c|}{1} & \multicolumn{2}{|c|}{2} & \multicolumn{2}{|c|}{3} & \multicolumn{2}{|c|}{4} \\
\hline & & & & & $\mathbf{f}$ & $\%$ & $\mathbf{f}$ & $\%$ & $\mathbf{f}$ & $\%$ & $\mathbf{f}$ & $\%$ \\
\hline \multirow{4}{*}{1} & \multirow{4}{*}{ Administrative } & Too much administrative work & 2.88 & 0.93 & 11 & 7 & 43 & 28 & 53 & 34 & 47 & 31 \\
\hline & & $\begin{array}{l}\text { Lack of sufficient time for } \\
\text { administrative work }\end{array}$ & 2.57 & 1.00 & 26 & 17 & 44 & 29 & 52 & 34 & 31 & 20 \\
\hline & & Evaluating staff effectively & 2.55 & 0.94 & 22 & 15 & 50 & 33 & 53 & 35 & 26 & 17 \\
\hline & & $\begin{array}{l}\text { Conducting effective classroom } \\
\text { visits }\end{array}$ & 2.52 & 0.94 & 21 & 14 & 55 & 36 & 49 & 32 & 26 & 17 \\
\hline \multirow{2}{*}{2} & \multirow{2}{*}{$\begin{array}{l}\text { Financial } \\
\text { management }\end{array}$} & Planning school finances & 2.65 & 1.03 & 23 & 15 & 48 & 31 & 43 & 28 & 40 & 26 \\
\hline & & Controlling school finances & 2.54 & 1.02 & 27 & 18 & 50 & 33 & 42 & 27 & 34 & 22 \\
\hline \multirow{2}{*}{3} & \multirow{2}{*}{ Work pressure } & Stress & 2.60 & 0.80 & 16 & 10 & 46 & 29 & 79 & 51 & 15 & 10 \\
\hline & & Tension & 2.54 & 0.86 & 20 & 13 & 48 & 31 & 70 & 45 & 17 & 11 \\
\hline 4 & Personal & $\begin{array}{l}\text { Giving sufficient attention to my } \\
\text { family }\end{array}$ & 2.72 & 0.95 & 21 & 14 & 34 & 22 & 66 & 43 & 34 & 22 \\
\hline \multirow{2}{*}{5} & \multirow{2}{*}{$\begin{array}{l}\text { Physical } \\
\text { resources }\end{array}$} & Supervising annual stock-taking & 2.62 & 1.01 & 26 & 17 & 41 & 27 & 52 & 34 & 35 & 23 \\
\hline & & Allocation of resources & 2.59 & 0.96 & 23 & 15 & 45 & 30 & 55 & 36 & 29 & 19 \\
\hline \multirow{3}{*}{6} & \multirow{3}{*}{ Staff } & $\begin{array}{l}\text { Gaining the cooperation of the } \\
\text { SMT }\end{array}$ & 2.57 & 1.01 & 27 & 17 & 45 & 29 & 50 & 32 & 33 & 21 \\
\hline & & Earning the loyalty of the SMT & 2.56 & 0.99 & 25 & 16 & 50 & 32 & 48 & 31 & 32 & 21 \\
\hline & & $\begin{array}{l}\text { Obtaining information about the } \\
\text { strengths of staff }\end{array}$ & 2.55 & 0.91 & 20 & 13 & 53 & 34 & 56 & 36 & 25 & 16 \\
\hline
\end{tabular}


cial planning encapsulates budgeting and strategic planning with regard to how to utilize the school's financial resources. Similarly, financial control implies that deputy principals need to take appropriate actions to ensure that school finance are used for the intended purposes. Financial management has been identified as a problem, which is generally experienced by SMTs in South African schools (Mestry \& Bisschoff, 2009). Therefore, deputy principals experience problems with financial planning and control, and they need professional development in this area.

\subsection{Work pressure problems}

Most of the deputy principals indicated that they experience stress (mean 2.60) and tension (mean 2.54) at their schools. The stress and tension are caused by the demands imposed on them by their new roles, and the anxiety to perform and meet expectations (Grayson \& Alvarez, 2008; Lashway, 2003; Oplatka \& Tamir, 2009). The transition from the lower post level of head of department to deputy principal brings adjustment problems for deputy principals, which may create work pressure problems for them. Deputy principals have professional and personal lives as well and if they neglect these, their stress and tension may increase. Again, some deputy principals are married and if they have family problems, this may lead to stress. Above all, if they lack coping mechanisms to deal with stress, it is likely to escalate.

\subsection{Personal problems}

Deputy principals experienced problems with giving sufficient attention to their family (mean 2.72). This personal problem stems from conflicting responsibilities of spending more time on work-related matters and not spending quality time with the family (South Africa, 1999). The deputy principal is a respected member of the community and may be required to assume certain leadership roles in the community. In addition, the deputy principal may be involved in extramural activities or serve in different committees whose activities take place after hours. In such cases, the deputy principal may have problems with giving sufficient attention to the family and this may result in problems relating to neglecting family responsibilities.

\subsection{Physical resources problems}

Deputy principals experienced problems with allocation of resources (mean 2.59) and supervising annual stock-taking (mean 2.62). The job description requires the deputy principal to assist the principal with allocation of resources and supervising annual stock-taking, among other duties (South Africa, 1999). Problems might be experienced when deputy principals lack management skills to perform these duties. Proper management of the school's infrastructure is a crucial management and governance task in view of the need to create a safe school environment, which is conducive to effective teaching and learning.

\subsection{Staff problems}

Staff problems that were experienced included gaining the cooperation (mean 2.57) and loyalty (mean 2.56) of the SMT and obtaining information about the strengths of staff (mean 2.55). Staff problems like the ones mentioned above are often experienced in an environment where the incumbent is newly appointed. Legotlo (1994) makes the point that a newcomer in any organization like a school is confronted by a multiplicity of challenges, like learning the ins and outs of school management and knowing how things are done in a new environment. It is argued in this paper that when an employee is newly appointed, there are people who expect them to prove themselves, while others do not support them, because they support the predecessor. Accordingly, the influence of the previous deputy principal may also create problems for the newly appointed deputy principal. The deputy principal's leadership style and the inability to communicate effectively may create staff problems for him/her.

\section{CONCLUSION}

In order to address the problems experienced by deputy principals, it is recommended that a context-specific induction program should be developed. Such an induction program should be viewed as an ongoing program of professional development and not a once-off event. The induction program 
could address problems experienced during the pre-service, induction and continuing professional development phases. The induction program should ideally comprise specific aims, action steps to be taken to achieve the aims that are set, and measures to evaluate progress.

The pre-service training of deputy principals by means of a formal qualification or on-the-job training should cover those areas of school management and leadership in which deputy principals experience problems upon appointment. This step will help with addressing the problems experienced during the pre-service phase.

Short courses could be developed to address the induction needs of newly appointed deputy principals. These short courses may focus on administrative and management aspects that form the core duties and responsibilities of deputy principals. Examples of such targeted short courses could include school administration, financial management, self-management, personnel management and other serious problems, which were identified in this study.

Future research into the deputy principalship may focus on problems experienced by primary school deputy principals. Such studies might be conducted in a bigger study population than the one that was considered for this study. Moreover, a qualitative approach can enable the researchers to hear the participants' voices, which did not happen in this study, as this was a quantitative study. A longitudinal study may also be undertaken to determine the problems that deputy principals experience when they assume duty, and a follow-up study after they have completed at least three years of service.

\section{ACKNOWLEDGEMENTS}

The authors would like to acknowledge the participation of secondary school deputy principals who participated in the study. Thanks are also due to the Statistical Consultation Services of the North West University who assisted with data analysis and the university for the bursary for the study on which this article is based.

\section{REFERENCES}

1. Barnett, B. G., Shoho, A. R., \& Oleszewsky, A. M. (2012). The job realities of beginning and experienced assistant principals. Leadership and Policy in schools, 11(1), 92-128. Retrieved from https://eric.ed.gov/?id=EJ955937

2. Boyle, B., Lamprianou, I., \& Boyle, T. (2005). A longitudinal study of teacher change: what makes professional development effective? School Effectiveness and School Improvement, 16(1), 1-27. https://doi. org/10.1080/09243450500114819

3. Cohen, L., Manion, L., \& Morrison, K. (2011). Research methods in education (7th ed.). London: Routledge.

4. Cranston, N., Tromans, C., \& Reugebrink, M. (2004). Forgotten leaders: what do we know about the deputy principalship in secondary schools? International Journal of Leadership in Education, 7(3), 225-242. https://doi.org/10.10 80/13603120410001694531

5. Creswell, J. W. (2014). Research design: qualitative, quantitative and mixed methods approaches (4th ed.). Thousand Oaks, California: SAGE.

6. Grayson, J. L., \& Alvarez, H. K. (2008). School climate factors relating to teacher burnout: a mediated model. Teaching and Teacher Education, 24(1), 13491363. Retrieved from https://eric. ed.gov/?id=EJ794697

7. Greenfield, W. D. (1985). The moral socialization of school administrators: informal roe learning outcome. Educational administration quarterly, 21(4), 99-119.
8. Harris, A., Muijs, D., \& Crawford, M. (2003). Deputy and assistant head: building leadership potential. Nottingham, UK: National College for School Leadership.

9. Heystek, J. H. (2012). Financial management in context. In J. W. Van Rooyen (Ed.), Financial Management in Education in South Africa. Pretoria: Van Schaik.

10. Khumalo, J. B., Van Vuuren, H. J., Van der Westhuizen, P. C., \& Van der Vyver, C. P. (2017). The Professional Development Needs Analysis Questionnaire for Deputy Principals. Africa Education Review, 14(2), 192-208.

11. Kitavi, M. (1995). The induction of beginning school principals in Kenya (Ph.D.). Potchefstroom University for Christian Higher Education, Potchefstroom. 
12. Kwan, P. (2009). The vice-principal experience as a preparation for the principalship. Journal of Educational Administration, 47(2), 191-205. https://doi. org/10.1108/09578230910941048

13. Lashway, L. (2003). Inducting school leaders. University of Oregon: ERIC Digest.

14. Le Maistre, C., \& Paré, A. (2010). Whatever it takes: how beginning teachers learn to survive. Teaching and Teacher Education, 26(1), 559-564.

15. Legotlo, M. W. (1994). An induction programme for newly appointed principals in Bophuthatswana (Ph.D. Thesis). NWU: Potchefstroom.

16. Maake, M. (2013). Educators' experiences of the induction process by principals (M Ed.). University of Pretoria, Pretoria.

17. Maree, K., \& Pietersen, J. (2016). Sampling. In K. Maree (Ed.), First steps in research (2nd ed.). Pretoria: Van Schaik.

18. Marshall, C. (1992). The assistant principal: leadership choices and challenges. Thousand Oaks, CA: Corwin Press.

19. Mathebula, T. (2005). The role of Representative Councils for Learners in South African schools: maximal or minimal participation? Africa Education Review, 2(2), 189-204.

20. Mentz, K., Challens, B., \& Kruger, A. G. (2016). Efficient financial management-leadership in schools. In I. Van Deventer (Ed.),
An educator's guide to school management-leadership skills (2nd ed.). Pretoria: Van Schaik.

21. Mestry, R., \& Bisschoff, T. (2009). Financial school management explained (3rd ed.). Cape Town: Pearson.

22. Mncube, V. (2008). Democratisation of education in South Africa: issues of social justice and the voice of learners? South African Journal of Education, $28,77-90$.

23. Msila, V., \& Mtshali, J. (2011). Professional development of principals: a recipe for future schools? British Journal of Educational Research, 1(1), 1-17.

24. Oplatka, I., \& Tamir, V. (2009). I don't want to be a school head: women deputy heads insightful constructions of career advancement and retention. Educational Management, Administration \& Leadership, 37(2), 216-238

25. Peloyahae, T. H. (2005). The management of induction programme for newly appointed educators in the Ekurhuleni West district (M Ed.). University of Johannesburg, Johannesburg.

26. Potgieter, P. C. (1990). Die inskakeling van nuutaangestelde adjunk-hoofde van sekondere skole [The induction of newly appointed deputy principals of secondary schools] (M Ed). Potchefstroomse Universiteit vir Christelike Hoer Onderwys [Potchefstroom University for Christian Higher Education], Potchefstroom.
27. Seipobi, T. T. (2012). Challenges and training needs of promoted school managers in Xhariep district secondary schools (M Ed.) Central University of Technology, Bloemfontein.

28. Smit, C. A. (2002). Die professionele ontwikkeling van die nuutaangestelde kringbestuurder in die onderwys deur middel van ' $n$ inskakelingsprogram [The professional development of newly appointed circuit managers by means of an induction programme] (Ph.D.). Potchefstroomse Universiteit vir Christelike Hoer Onderwys [Potchefstroom University for Christian Higher Education], Potchefstroom.

29. Somo, M. P. (2007). The perceptions, experiences and expectations of educators about their own professional development in schools (M Ed.). University of Pretoria, Pretoria.

30. South Africa (1999). Personnel Administrative Measures (PAM). Pretoria: Government Printer.

31. Steyn, G. M. (2011). Continuing professional development in South African schools: staff perceptions and the role of principals. Journal of Social Sciences, 28(1), 43-53.

32. Van der Westhuizen, P. C. (1991). Educational management tasks. In P. C. Van der Westhuizen (Ed.), Effective educational management. Cape Town: Kagiso Tertiary.

33. Van Deventer, I. (2016). Control and accountability as management-leadership tasks. In I. Van Deventer (Ed.), An educator's guide to school management-leadership skills (2nd ed.). Pretoria: Van Schaik. 